\title{
Men's perceptions of and participation in family planning in Aqaba and Ma'an governorates, Jordan
}

A.M. Hamdan-Mansour, ${ }^{1}$ A.O. Malkawi, ${ }^{2}$ T. Sato, ${ }^{3}$ S.H. Hamaideh ${ }^{4}$ and S.I. Hanouneh ${ }^{5}$

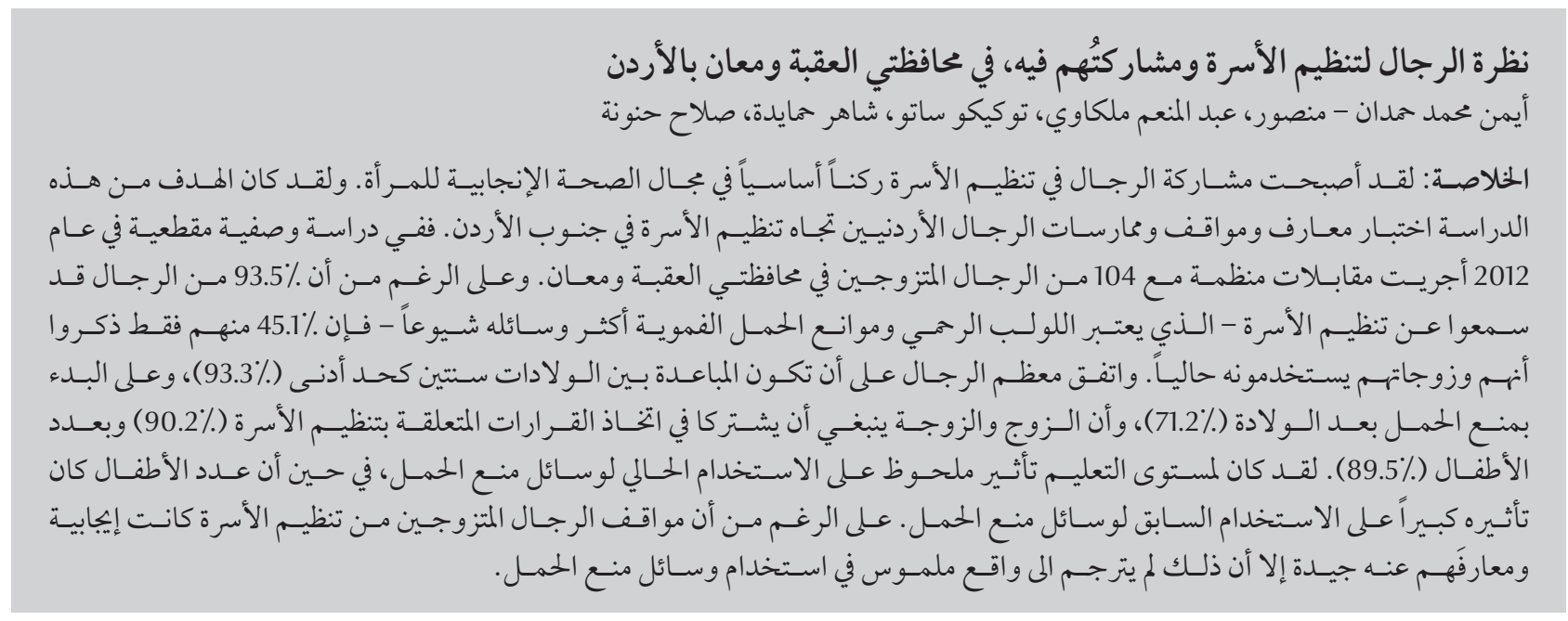

ABSTRACT Men's participation in family planning has become a cornerstone in women's reproductive health. The aim of this study was to examine knowledge, attitudes and practice towards family planning of Jordanian men in southern Jordan. In a cross-sectional descriptive study in 2012, structured interviews were made with 104 married men in Aqaba and Ma'an governorates. Although 93.5\% of the men had heard about family planning-most commonly the intrauterine device (IUD) and oral contraceptives-only $45.1 \%$ reported that they and their wife currently used it. Most men agreed about a minimum 2 years' child spacing $(93.3 \%)$ and starting contraception after childbirth (71.2\%) and that husband and wife should share decisions about family planning (90.2\%) and the number of children (89.5\%). Level of education significantly affected current use of contraception, while number of children significantly affected previous use of contraception. Although married men had positive attitudes and good knowledge about family planning, this did not translate into practice of contraceptive use.

Perception et implication des hommes en matière de planification familiale dans les gouvernorats de Ma'an et d'Akaba (Jordanie)

RÉSUMÉ L'implication des hommes dans la planification familiale est devenue une composante essentielle de la santé génésique des femmes. La présente étude, conduite dans le sud de la Jordanie, avait pour but d'étudier les connaissances, les attitudes et les pratiques des hommes jordaniens en matière de planification familiale. Dans le cadre d'une étude transversale descriptive menée en 2012, des entretiens structurés ont été réalisés auprès de 104 hommes mariés dans les gouvernorats d'Akaba et de Ma'an. Alors que 93,5 \% d'entre eux avaient entendu parler de la planification familiale (en particulier, le plus souvent, du dispositif intra-utérin [DIU] et des contraceptifs oraux), seuls 45,1\% ont indiqué qu'ils y avaient actuellement recours avec leurs épouses. La plupart des hommes convenaient de la nécessité d'espacer les naissances d'au moins deux ans (93,3\%) et de mettre en place une contraception juste après l'accouchement (71,2\%). Ils approuvaient également le fait que les décisions relatives à la planification familiale $(90,2 \%)$ et au nombre d'enfants $(89,5 \%)$ devaient être prises d'un commun accord entre mari etfemme. Il existait une incidence significative entre le niveau d'études et la contraception en cours ainsiquelenombre d'enfants etl'utilisation antérieure d'un moyen de contraception. Siles hommes mariés avaientune attitude positive vis-à-vis de la planification familiale et de bonnes connaissances en la matière, ceci ne se traduisait pas, en pratique, parl'utilisation d'une méthode de contraception.

'School of Nursing, University ofJordan, Amman, Jordan (Correspondence to A.M. Hamdan-Mansour: a.mansour@ju.edu.jo). 2Jordan River Foundation, Amman, Jordan. Jjapan International Cooperation Agency, Amman, Jordan. ${ }^{4}$ Faculty of Nursing, Hashemite University, Zarqa, Jordan. ${ }^{5}$ Al-Farabi Colleges, Riyadh, Saudi Arabia.

Received: 25/01/15; accepted: 02/11/15 


\section{Introduction}

A major issue identified as a cornerstone of women's reproductive health is male participation in family planning practices. The International Conference on Population and Development in 1995 affirmed the notion of the responsibilities of men in reproductive health, and emphasized their active involvement (1). Men's involvement includes encouraging the use of male methods and expanding men's involvement in family decision-making $(2,3)$. Nevertheless, most reproductive health and family planning programmes target women, and health workers who are responsible for delivering family planning services tend to focus on women when discussing and implementing family planning issues. Moreover, efforts to promote use of family planning have focused primarily on women, assuming that they have the major role in making decisions related to family planning. Therefore, despite some promising reports (4-6), men's role in family planning has been a neglected topic of research.

In Jordan, low male participation in family planning is considered as one of the obstacles to quality reproductive health care delivery (7). However, any discussions of men's involvement in family planning must include their views on ideal family size. Men's fertility preferences play a major role in men's perception of the importance of family planning and the need for reproductive health services. In Jordan, the Higher Population Council reported that men and women prefer male children, and that Jordanian families believe that more male children reflects a man's virility and authority (6). Therefore, the desire to have a male child was found to be an obstacle to family planning programmes (7). Another issue is family size. Jordanians - regardless of age, type of residence or educational background-reported that the ideal number of children is $4-5$, while the total fertility rate is $5.9(7)$. The fact that Jordanian families prefer large families reflects the effect of social norms and cultural influences on decision-making in relation to implementation and preference of family planning methods (7). However, men's ability to achieve the desired family size depends on their level of awareness about family planning methods.

Surveys of men's knowledge about family planning in 46 countries found that men were more likely than women to know about family planning (2). Nonetheless, men were less likely than women to approve of family planning. While $88 \%$ of Jordanian men believe that Islam approves of family planning, lack of knowledge about the Islamic stance on the use of specific methods, and limited knowledge about the safety, reversibility and effectiveness of modern methods, were considered major barriers to men's involvement in family planning (8). A number of studies have addressed male participation and involvement in family planning (9-11). Among Jordanians aged 15-24 years $29 \%$ of females and $44 \%$ of males reported not understanding the meaning of the term reproductive health (12). Barriers such as access to information, inclusion in national reproductive health programmes and addressing need in national health plans contribute to Jordanian male's lack of knowledge $(12,13)$.

Efforts that target men in family planning programmes in Jordan are still limited and almost ignored in the national campaigns. Increasing men's awareness about family planning is expected to improve access to and utilization of family planning methods among Jordanian families (7). This study was planned to address this issue and to increase our understanding of Jordanian men's perceptions and knowledge about family planning practices and their current and previous use of contraceptive methods. The study also explored men's attitudes to family planning decision-making and the factors affecting their use of contraception.

\section{Methods}

The survey was conducted in 2012 and used a cross-sectional, descriptive design. Structured, household interviews were carried out by trained interviewers on a sample of married men in villages in the southern region of Jordan.

\section{Sample and setting}

The sample of married men was recruited using stratified random sampling from 2 governorates in southern Jordan, based on their geographical area and the population density. The estimated sample size was 110 households. The sampling resulted in 6 villages from the 2 governorates of Aqaba and Ma'an. The Jordanian Department of Statistics provided the 6 randomly selected villages and house blocks for a study area. The inclusion criteria were: evermarried men above the age of 18 years. A total of 104 married men completed the study: 40 from Ma'an governorate and 54 from Aqaba governorate.

\section{Data collection}

\section{Study tool}

The data collection tool was developed in English language by the research team utilizing a thorough review of the literature and information and tools available at the Jordanian Ministry of Health and the Higher Population Council. Two researchers who were bilingual in Arabic and English-one of them an author (T.A.) and the other a health academic - unified the Arabic text. Then 2 bilingual health professionals familiar with health terminology in both Arabic and English-one of them experienced in the use of health research studies within the Arabic community - compared the Arabic version with the English original. Back-translation of Arabic to English was conducted by 2 independent 
translators - a professional translator and a bilingual health academicwho were blind to the original English version. The final version of the tool was checked for face validity using an expert panel. All the required modifications were done in agreement between the expert panels. Then a pilot study of 20 participants was used to check on the clarity and cultural appropriateness of the questions and the time required to fill out the survey.

The survey comprised 3 parts. The first part was knowledge about family planning (10 items), in which men were asked to respond to questions such methods of family planning and what they know about these methods. The second part was attitudes towards family planning (31 items), in which men responded to questions about their perceptions of contraceptive use and whether women needed to use contraceptive methods. The third part covered decision-making related to family planning (10 items) and asked the men to respond to questions such as who was responsible for choosing the contraceptive method and what was the role of women in making such decisions. In addition, the survey collected data about the demographic characteristics of the participants. All questions were presented in Arabic language

\section{Procedure}

Prior to data collection, ethical approval was obtained from the target collaborating institutions. The interviewers then visited the selected households and interviewed eligible respondents. Participants were asked to sign a consent form that included information about the purpose of the study, its significance and what was expected from them. They were also assured about the confidentiality of the study data and that they had the right to refuse participation in the study and could withdraw at any time during they study. They were informed that they would be asked questions related to reproductive health and the data would be collected using an interview. During the structured interview, the research assistant who conducted the interviews provided a standard introduction for all participants, including an explanation of the format of the interview, the questions to expect, and how responses were going to be recorded. After asking an interview question, the researcher probed the man's answer for greater detail. The researcher concluded the interview by thanking the man, outlining the next steps and providing him with an opportunity to ask any other questions.

\section{Data analysis plan}

Statistical analysis was performed using SPPS, version 17.0. First the data was screened and cleaned for missing and extreme values. The data were examined for patterns of missing values and then appropriate techniques were used to manage missing data. Descriptive statistics in terms of central tendency (mean, median and mode) and dispersion measures (standard deviation and variance), in addition to frequency distribution and percentages were used to answer the research questions. The descriptive statistics obtained were compared with other normative samples in the literature. The chi-squared test was used to test differences across the knowledge, attitudes and decisionmaking domains in relation to selected demographic characteristics of the participants.

\section{Results}

\section{Demographic characteristics}

The mean age of the participants was 42.6 (SD 12.9) years, ranging from 22 to 72 years. Most of the participants (90.3\%) had 1 wife and $9.7 \%$ of them had 2 wives (see Table 1). None of the participants had more than 2 wives. The number of births ranged from 0 to 22 children with average number of
5.5 (SD 4.5). In addition, $98.0 \%$ of the participants reported that they wished to have more children.

Most of the men (90.4\%) had received some schooling ever in their life. Among those who had been to school, 92.3\% had high secondary or lower level of education, while $7.7 \%$ had a diploma, baccalaureate or master's degree. Regarding practices of reading as a source of information, most of the men reported that they did not read (52.0\%). Of those who read, they were reading about twice a week to once a month (27.4\%), indicating that hardcopy material was not their preferred source of information.

\section{Knowledge about family planning}

The analysis of the knowledge scale showed that $93.5 \%$ of the married men reported that they have heard about family planning, and $90.9 \%$ of them had heard about a method to prevent pregnancy (Table 2). When asked what methods they had heard about, more than three-quarters of the men had heard about the intrauterine device (IUD) (74.0\%) and oral contraceptive pills (79.0\%). In addition, $37.0 \%$ of them reported hearing about injections, external ejaculation and the male condom. None of the men had ever heard about using spermicidal foam or rubber membranes (female condom).

When asked about use of contraception $45.1 \%$ of the men reported currently using a method of contraception with their wife, with the highest use for the IUD (74.0\%), external ejaculation $(20.9 \%)$ and oral contraceptives (14.0\%). A similar proportion of respondents had previously used a method of contraception (45.7\%), most commonly oral contraceptives (51.2\%) or IUD (34.9\%). However, a much higher proportion of the participants (63.6\%) thought that they and their wife would use contraceptive methods in the future. 


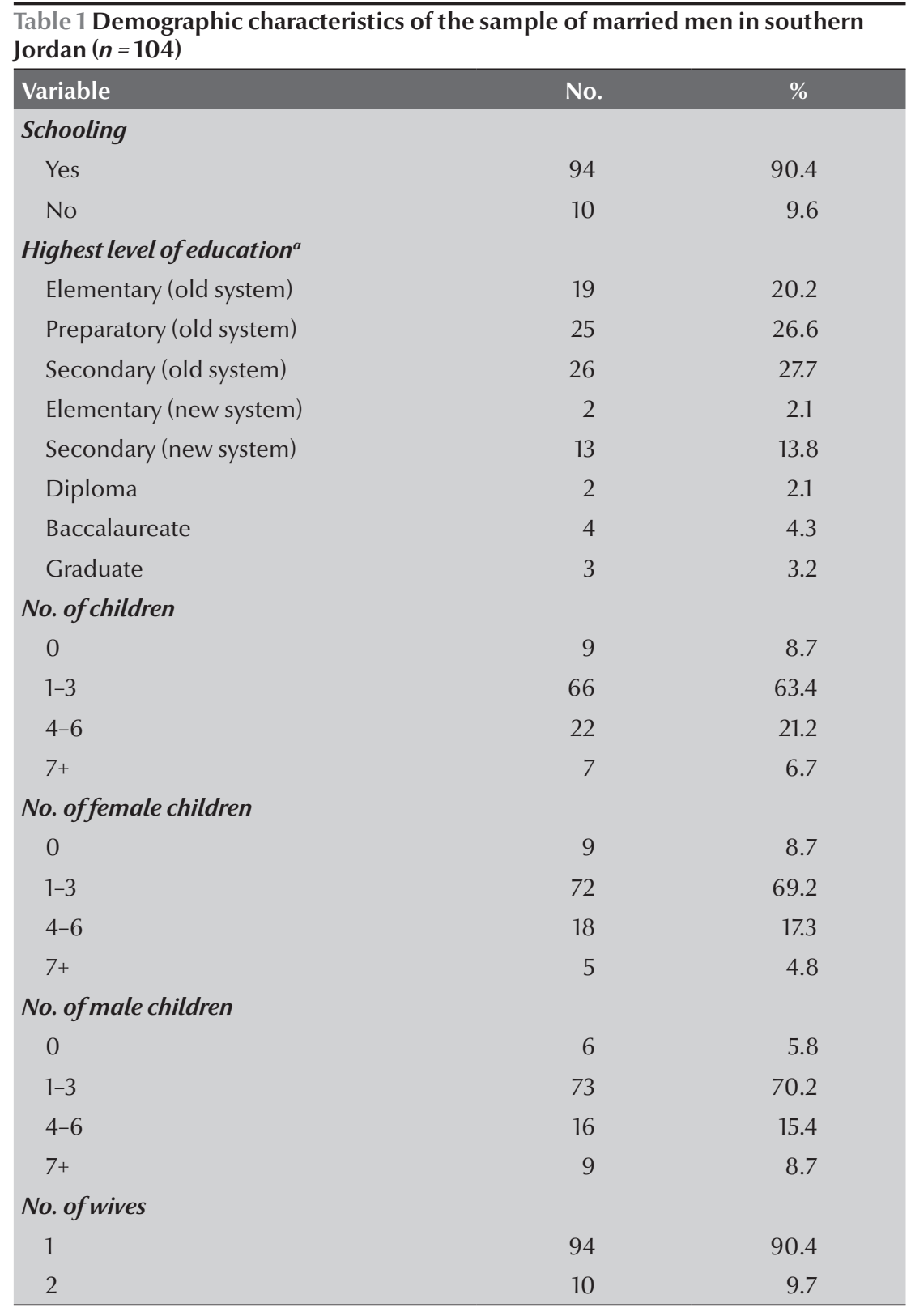

Data were missing in some categories.

${ }^{a}$ Due to changes in the educational system in Jordan classes 10-12 were previously considered secondary, while in the new system only classes 11-12 are secondary.

\section{Attitudes toward family planning}

Regarding thesemen's attitudes towards family planning, the results showed very positive attitudes to almost all items of the scale (Table 3). There were high agreement rates about: having at least 2 years' spacing between children (93.3\%), starting contraception immediately after childbirth (71.2\%), the health benefits of spacing for the next child (99.0\%), the advantages of contraception in upbringing and meeting the needs of their children (95.2\%), encouraging wives to use contraception (82.7\%), accompanying wives in their visits to family planning centres (70.2\%) and discussing family planning issues with the physician (78.8\%).

On the other hand, there was a high rate of disagreement about: family planning being the woman's responsibility and that the man had a passive role (85.6\%), a woman's preference not to talk to her husband about family planning (76\%), a man's preference for not talking about family planning with his wife (77\%) and a woman's preference not having her husband interfere with family planning decisions (82.7\%). Interestingly, married men did not agree that having more children was proof of their masculinity (75.0\% disagreed), and they were only moderately in agreement with the notion that a man should be proud of having more children (54.8\% disagreed).

\section{Decision-making within the family}

Regarding who made the important decisions in the family related to use and selection of family planning methods (Table 4), the great majority of participants reported that both husband and wife are responsible for decisions related to family planning $(90.2 \%)$ and the number of children (89.5\%). The results also showed that a majority of the participants agreed that both husband and wife are responsible for decisions about daughters' and sons' education ( $76.5 \%$ and $75.5 \%$ respectively).

Moreover, $79.4 \%$ of married men reported that they discussed with their wife decisions related to their family life. On the other hand, men in this survey showed some negative attitudes to wives' contributions to some important decisions (Table 4). Although participants reported that their wife always made the decisions related to her own health (66.7\%) and that she was always allowed to discuss any decisions he made (50\%), they also said that he always made the important decisions related to the family (63.7\%). Furthermore only $51.0 \%$ of men sometimes allowed their wife to make all the decisions related to her life and $56.9 \%$ sometimes accepted their wife's objection to decisions that he made.

\section{Variables associated with current and previous contraceptive use}

Chi-squared testing was used to examine the difference in the current and previous use of contraceptive methods 


\begin{tabular}{|c|c|c|}
\hline \multicolumn{3}{|c|}{$\begin{array}{l}\text { Table } 2 \text { Knowledge and use of family plar } \\
\text { among married men in southern Jordan }\end{array}$} \\
\hline Variable & No. & $\%$ \\
\hline \multicolumn{3}{|l|}{$\begin{array}{l}\text { Did you hear about family } \\
\text { planning? }(n=92)\end{array}$} \\
\hline Yes & 86 & 93.5 \\
\hline No & 6 & 6.5 \\
\hline \multicolumn{3}{|c|}{$\begin{array}{l}\text { Did you hear about methods to prevent } \\
\text { pregnancy? }(n=88)\end{array}$} \\
\hline Yes & 80 & 90.9 \\
\hline No & 8 & 9.1 \\
\hline \multicolumn{3}{|c|}{$\begin{array}{l}\text { Methods heard about to prevent } \\
\text { pregnancy }(n=80)\end{array}$} \\
\hline Female sterilization & 3 & 3.8 \\
\hline Male sterilization & 3 & 3.8 \\
\hline Oral contraceptive pills & 64 & 80.0 \\
\hline IUD & 60 & 75.0 \\
\hline Injection & 30 & 37.5 \\
\hline Implants & 2 & 2.5 \\
\hline Male condom & 23 & 28.8 \\
\hline Female condom & 1 & 1.3 \\
\hline Rubber membrane & 0 & 0.0 \\
\hline Spermicidal foam & 0 & 0.0 \\
\hline Prolonged breastfeeding & 6 & 7.5 \\
\hline Counting & 2 & 2.5 \\
\hline External ejaculation & 25 & 31.3 \\
\hline Did not know any method & 6 & 7.5 \\
\hline Others & 0 & 3.8 \\
\hline \multicolumn{3}{|c|}{$\begin{array}{l}\text { Do you use any contraceptive method } \\
\text { now? }(n=90)\end{array}$} \\
\hline Yes & 41 & 45.6 \\
\hline No & 49 & 54.4 \\
\hline \multicolumn{3}{|l|}{ Method used $(n=41)$} \\
\hline Female sterilization & 4 & 9.8 \\
\hline Male sterilization & 0 & 0.0 \\
\hline Oral contraceptive pills & 6 & 14.6 \\
\hline IUD & 12 & 29.3 \\
\hline Injection & 6 & 14.6 \\
\hline Implants & 1 & 2.4 \\
\hline
\end{tabular}

\begin{tabular}{|c|c|c|}
\hline \multicolumn{3}{|c|}{$\begin{array}{l}\text { Table } 2 \text { Knowledge and use of family planning methods } \\
\text { among married men in southern Jordan (concluded) }\end{array}$} \\
\hline Variable & No. & $\%$ \\
\hline Male condom & 2 & 4.9 \\
\hline Female condom & 1 & 2.4 \\
\hline Rubber membrane & 0 & 0.0 \\
\hline Spermicidal foam & 0 & 0.0 \\
\hline Prolonged breastfeeding & 0 & 0.0 \\
\hline Counting & 3 & 7.3 \\
\hline External ejaculation & 9 & 22.0 \\
\hline \multicolumn{3}{|c|}{$\begin{array}{l}\text { Did you use any method in the } \\
\text { past? }(n=92)\end{array}$} \\
\hline Yes & 42 & 45.7 \\
\hline No & 50 & 54.3 \\
\hline \multicolumn{3}{|c|}{ Methods used in the past $(n=42)$} \\
\hline Female sterilization & 0 & 0.0 \\
\hline Male sterilization & 1 & 2.4 \\
\hline Oral contraceptive pills & 22 & 52.4 \\
\hline IUD & 15 & 35.7 \\
\hline Injection & 5 & 11.9 \\
\hline Implants & 0 & 0.0 \\
\hline Male condom & 5 & 11.9 \\
\hline Female condom & 0 & 0.0 \\
\hline Rubber membrane & 0 & 0.0 \\
\hline Spermicidal foam & 0 & 0.0 \\
\hline Prolonged breastfeeding & 3 & 7.1 \\
\hline Counting & 1 & 2.4 \\
\hline External ejaculation & 6 & 14.3 \\
\hline \multicolumn{3}{|c|}{$\begin{array}{l}\text { Who makes the decision to use } \\
\text { contraceptives? }(n=46)\end{array}$} \\
\hline Husband & 1 & 2.2 \\
\hline Wife & 1 & 2.2 \\
\hline Husband and wife & 44 & 95.7 \\
\hline \multicolumn{3}{|c|}{$\begin{array}{l}\text { Do you think that you and your wife } \\
\text { will use contraceptive methods in the } \\
\text { future? }(n=87)\end{array}$} \\
\hline Yes & 57 & 65.5 \\
\hline No & 30 & 34.5 \\
\hline
\end{tabular}

$I U D=$ intrauterine device. in relation to demographic characteristics and attitudes (Table 5). The analysis showed that the man's level of schooling, level of education and number of children in the family were significant factors affecting current use of contraception. Those who had been to school had a significantly higher rate of contraceptive use than those who had not $\left(\chi^{2}=3.99, P=0.04\right)$ and those who had higher level of education had higher rates of current contraceptive use ( $100 \%$ of graduates) $\left(\chi^{2}=13.5, P=\right.$ $0.021)$. Moreover, those who had more children had lower rates of current use of contraceptives: $32.1 \%$ of those who had $7+$ children versus $52.8 \%$ of those with $1-3$ children $\left(\chi^{2}=23.3, P=\right.$ $0.024)$. However, in relation to previous use of contraception, there were no significant differences related to any of these factors, although those who had been to school had a marginally higher level with contraceptive use $\left(\chi^{2}=3.8\right.$, $P=0.051)$. No significant differences were found in the respondents' current and previous use of contraceptive methods in relation to age, number of wives, level of education and ever having children. 


\begin{tabular}{|c|c|c|c|}
\hline Item & $\begin{array}{l}\text { Agree } \\
\%\end{array}$ & $\begin{array}{c}\text { Neutral } \\
\%\end{array}$ & $\begin{array}{c}\text { Disagree } \\
\%\end{array}$ \\
\hline Couples must have at least 2 years of birth spacing & 93.3 & 2.9 & 3.8 \\
\hline Couples must have at least $3-5$ years of birth spacing & 42.3 & 19.2 & 38.2 \\
\hline $\begin{array}{l}\text { Couple must use method/s of contraception immediately after childbirth and } \\
\text { before they resume their sexual relationship }\end{array}$ & 71.2 & 6.7 & 22.1 \\
\hline If couples had the right spacing, the next child will be healthier & 99.0 & 1.0 & 0.0 \\
\hline If couples postpone the next child, the mother's health will be better & 99.0 & 1.0 & 0.0 \\
\hline Having more children is a source of pride & 36.5 & 8.7 & 54.8 \\
\hline Having more children is a matter of masculinity for the man & 19.2 & 5.8 & 75.0 \\
\hline Having more children is a proof of fertility for women & 16.3 & 10.6 & 73.1 \\
\hline Family planning allows parents to raise their children and meet their needs & 95.2 & 2.9 & 1.9 \\
\hline $\begin{array}{l}\text { If the child is a female, then the women should keep getting pregnant until she } \\
\text { gets a boy }\end{array}$ & 30.8 & 15.4 & 53.8 \\
\hline $\begin{array}{l}\text { Family planning is the woman's responsibility and the man has nothing to do } \\
\text { with that }\end{array}$ & 11.5 & 2.9 & 85.6 \\
\hline In general, women prefer not talking about family planning with their husbands & 10.6 & 13.5 & 76.0 \\
\hline In general, men prefer not talking about family planning with their wives & 15.4 & 7.7 & 76.9 \\
\hline $\begin{array}{l}\text { In general, women prefer not having their husbands interfere with their family } \\
\text { planning decisions }\end{array}$ & 7.7 & 9.6 & 82.7 \\
\hline Men have to encourage their wives to use family planning methods & 82.7 & 7.7 & 9.6 \\
\hline Man has to accompany his wife in her visit to the family planning centre & 70.2 & 12.5 & 17.3 \\
\hline $\begin{array}{l}\text { Man has to discuss with health care provider (physician) the options available } \\
\text { for using family planning methods }\end{array}$ & 78.8 & 9.6 & 11.5 \\
\hline
\end{tabular}

Regarding the difference in current and previous use of contraceptive methods in relation to their attitudes toward family planning, the analysis showed significant differences in relation to using method/s of contraception immediately after childbirth and before resuming their sexual relationship $\left(\chi^{2}\right.$ $=7.33, P=0.03)$, a woman's preference to not to talk about family planning with her husband $\left(\chi^{2}=6.46, P=0.04\right)$, and a woman's preference not to have her husband interfere with her family planning decisions $\left(\chi^{2}=7.52, P=0.02\right)$.
However, previous use of contraceptive methods was significantly affected by married men's attitudes to having more children as a matter of masculinity for the man $\left(\chi^{2}=6.14, P\right.$ $=0.04$ ), a man's preference not to talk about family planning with their wife $\left(\chi^{2}\right.$

\begin{tabular}{|c|c|c|c|}
\hline \multirow[t]{2}{*}{ Item } & $\%$ & $\%$ & $\%$ \\
\hline & Both & Wife & Husbanc \\
\hline Who is responsible for making the decision related to family planning use? & 90.2 & 1.0 & 8.8 \\
\hline Who is responsible for making the decision related to daughters' education? & 76.5 & 7.8 & 15.7 \\
\hline Who is responsible for making the decision related to sons' education? & 75.5 & 1.0 & 23.5 \\
\hline \multirow[t]{2}{*}{ Who is responsible for making the decision related to number of children? } & 89.5 & 1.0 & 9.6 \\
\hline & Never & Sometimes & Always \\
\hline $\begin{array}{l}\text { My wife has the right to make decisions related to her life, such as education, } \\
\text { work, pregnancy, using contraceptive methods }\end{array}$ & 23.5 & 51.0 & 25.5 \\
\hline I discuss with my wife decisions related to our family and life & 2.0 & 18.6 & 79.4 \\
\hline I accept my wife's objections on some of my decisions & 14.7 & 56.9 & 28.4 \\
\hline My wife has the right to make decisions related to her health & 2.0 & 31.7 & 66.3 \\
\hline I make all important decisions related to my family & 9.8 & 26.5 & 63.7 \\
\hline I allow my wife to discuss any decision I make & 7.8 & 42.2 & 50.0 \\
\hline
\end{tabular}




\begin{tabular}{|c|c|c|c|c|c|c|c|c|}
\hline \multirow[t]{3}{*}{ Variable } & \multicolumn{2}{|c|}{ Current use } & \multirow[t]{3}{*}{$\chi^{2}$} & \multirow[t]{3}{*}{$P$-value } & \multicolumn{2}{|c|}{ Previous use } & \multirow[t]{3}{*}{$x^{2}$} & \multirow[t]{3}{*}{$P$-value } \\
\hline & Yes & No & & & Yes & No & & \\
\hline & $\%$ & $\%$ & & & $\%$ & $\%$ & & \\
\hline \multicolumn{9}{|l|}{ Schooling } \\
\hline Yes & 52.2 & 47.8 & 3.99 & 0.040 & 48.2 & 51.8 & 3.88 & 0.051 \\
\hline No & 12.5 & 87.5 & & & 12.5 & 87.5 & & \\
\hline \multicolumn{9}{|l|}{ Highest level of education } \\
\hline Elementary (old system) & 31.3 & 62.5 & 13.5 & 0.021 & 31.3 & 68.7 & 5.74 & 0.403 \\
\hline Preparatory (old system) & 54.2 & 45.8 & & & 54.2 & 45.8 & & \\
\hline Secondary (old system) & 37.5 & 62.5 & & & 37.5 & 62.5 & & \\
\hline Elementary (new system) & 0.0 & 100.0 & & & 0.0 & 0.0 & & \\
\hline Secondary (new system) & 70.0 & 30.0 & & & 70.0 & 30.0 & & \\
\hline Diploma & 50.0 & 50.0 & & & 50.0 & 50.0 & & \\
\hline Baccalaureate & 66.7 & 33.3 & & & 66.7 & 33.3 & & \\
\hline Graduate & 100.0 & 0.0 & & & 100.0 & 0.0 & & \\
\hline \multicolumn{9}{|l|}{ No. of children } \\
\hline 0 & 0.0 & 0.0 & 23.3 & 0.024 & 0.0 & 0.0 & 2.77 & 0.117 \\
\hline $1-3$ & 52.8 & 47.2 & & & 50.0 & 50.0 & & \\
\hline $4-6$ & 52.0 & 48.0 & & & 56.0 & 44.0 & & \\
\hline $7+$ & 32.1 & 64.0 & & & 34.5 & 65.5 & & \\
\hline \multicolumn{9}{|l|}{ No. offemale children } \\
\hline 0 & 66.7 & 33.3 & 4.92 & 0.055 & 83.3 & 16.7 & 4.30 & 0.113 \\
\hline $1-3$ & 49.2 & 50.8 & & & 45.0 & 55.0 & & \\
\hline $4-6$ & 42.1 & 57.9 & & & 42.1 & 57.9 & & \\
\hline $7+$ & 14.3 & 85.7 & & & 28.6 & 71.4 & & \\
\hline \multicolumn{9}{|l|}{ No. of male children } \\
\hline 0 & 50.0 & 50.0 & 5.00 & 0.258 & 25.0 & 75.0 & 6.09 & 0.249 \\
\hline $1-3$ & 48.2 & 51.8 & & & 55.4 & 44.6 & & \\
\hline $4-6$ & 38.9 & 55.6 & & & 36.8 & 63.2 & & \\
\hline $7+$ & 33.3 & 66.7 & & & 22.2 & 77.8 & & \\
\hline
\end{tabular}

$=6.91, P=0.03)$, men having to encourage their wife to use family planning methods ( $\left.\chi^{2}=7.68, P=0.02\right)$, and the man having to discuss with a health care provider the options available for family planning $\left(\chi^{2}=6.14, P=0.04\right)$.

\section{Discussion}

Women's health has become a priority at both the national and international levels. One major issue identified as a contributing factor and cornerstone in women's reproductive health is men's participation in family planning practices (2). This study aimed to address this issue and examine it among married men in the southern region of Jordan. The results showed that married men had good knowledge about family planning, and they had also used some forms of family planning. The study found that $45.1 \%$ of them reported currently using a method of contraception, mostly commonly IUD, external ejaculation or oral contraceptive pills. There were high rates of agreement about 2 years' spacing between children, using contraception after childbirth, the health benefits of contraception, the relationship between contraception and children's health needs, encouraging wives to use contraception, accompanying wives to family planning centres, and discussing family planning issues with a physician.

Although the results of this study agree with previous studies that men in Jordan do have good knowledge about family planning $(7,8)$, the finding that less than half of them used one these methods suggests that they have not invested their knowledge about the benefits of family planning towards actual use of contraception. The discrepancy in rates of willingness to use contraceptive methods in the future (63.3\%) and current and previous use of contraception (around 45\%) would 
question the commitment towards using contraception. In other studies in this region and elsewhere, lack of knowledge and access to reproductive health care services have been identified as the most likely reasons for not using family planning methods among males (9-11). The discrepancy between the rates of knowledge and the rates of transfer into practice prompts attention to the reasons for not using family planning methods. One explanation is that even though male Jordanians have heard about family planning, they may not have sufficient accurate information about methods of family planning in order to use them.

Our results about attitudes to family planning showed that both husbands and wives were in agreement about using contraceptives, which indicates that neither husband nor wives hindered contraceptive use. Furthermore, these married male Jordanians in the southern region did not agree that children were a source of pride (54.8\%) or that having more children would prove their masculinity $(75.0 \%)$. This suggests that the concept of the family in these southern Jordan communities may have shifted from the number of children to a more quality-of-life perspective. Previous studies reported that Jordanian men preferred male over female children and that social and cultural norms influence males' decision to use family planning methods $(6,7,14)$. However, the results of our study indicated that social and cultural norms did not influence men's decisions about family planning and that getting a male child was not a reason for avoiding contraception. The results contradict previous national and cultural studies related to the effect of culture on men which showed that men were exerting their power and not sharing decisions with their wives about the use and selection of family planning (15-17).

The great majority of men reported that both husband and wife made decisions related to family planning (90.2\%) and the number of children (89.5\%). However, the results related to men's perceptions about the process and type of decisions they and their wives made are also not easy to comprehend. Married men in some instances claimed that they gave their wife the authority to always make decisions about her own health (66.7\%), while in other cases they reported having the authority to always make all important decisions about the family (63.7\%) and not accepting their wife's objection to decisions they made ( $7.8 \%$ never, $42.2 \%$ sometimes). This may indicate that men believe that they have the power and authority and that they relinquish it and regain it whenever they wish. This puts women's health at risk, if it is subject to men's wishes and desires.

\section{Conclusion}

The study calls for an urgent need to target married men in Jordan in all health care plans and projects related to reproductive health. Although the men in our study had positive attitudes and good knowledge about family planning, these did not translate that into behaviours and practices. Therefore, there is a need to extend the role of health professionals at the maternal and child health care centres. Health education programmes should target married men at their place of living to effectively enrol them in all aspects of reproductive health care and provide them with accurate information.

\section{Funding: None.}

Competing interests: None declared.

\section{References}

1. Summary of the programme of action of the International Conference on Population and Development, Cairo, Egypt, 5-13 September 1994. New York (NY): United Nations, Department of Public Information; 1995.

2. Male involvement in reproductive health including family planning and sexual health. New York: United Nations Population Fund; 1995 (Technical Report 28).

3. Mistik S, Naçar M, Mazicioğlu M, Cetinkaya F. Married men's opinions and involvement regarding family planning in rural areas. Contraception. 2003 Feb;67(2):133-7. PMID:12586323

4. Hussain MA, Rahman GS, Begum N. Integration of male and female reproductive health services in Bangladesh with an emphasis on increasing male participation and awareness. Popul Rev. 2004;43:103-17.

5. Shahjahan M, Kabir M. Why males in Bangladesh do not participate in reproductive health: lessons learned from focus group discussions. Int Q Community Health Educ. 2006-20072007;26(1):45-59. PMID:17686713

6. Raju S, Leonard A. Men as supportive partners in reproductive health: moving from rhetoric to reality. New Delhi, India, Population Council, South and East Asia Regional Office; 2000.
7. Inventory of population studies. Amman, Jordan: Higher Population Council; 2005.

8. Kridli SA, Libbus K. Contraception in Jordan: a cultural and religious perspective. Int Nurs Rev. 2001 Sep;48(3):144-51. PMID:11558689

9. Bearinger LH, Sieving RE, Ferguson J, Sharma V. Global perspectives on the sexual and reproductive health of adolescents: patterns, prevention, and potential. Lancet. 2007 Apr 7;369(9568):1220-31. PMID:17416266

10. Dejong J, Shepard B, Roudi-Fahimi F, Ashford L. Young people's sexual and reproductive health in the Middle East and North Africa. Washington (DC): Population Reference Bureau; 2005 (http://www.igwg.org/pdf07/MENAYouthReproductiveHealth.pdf, accessed 7 December 2015).

11. Senderowitz J. Making reproductive health services youth friendly. Research, Program and Policy Series. Washington (DC): FOCUS on Young Adults; 1999 (http://www.pathfinder. org/publications-tools/pdfs/Making-Reproductive-HealthServices-Youth-Friendly.pdf, accessed 7 December 2015).

12. Almasarweh IS. Adolescent and youth reproductive health in Jordan: status, issues, policies, and programs. Washington 
(DC): POLICY Project, US Agency for International Development 2003 (http://www.policyproject.com/pubs/countryreports/ARH_Jordan.pdf, accessed 7 December 2015).

13. DeJong J, El-Khoury G. Reproductive health of Arab young people. BMJ. 2006 Oct 21;333(7573):849-51.

14. Mahadeen A, Othman A, Hamdan-Mansour A, Sato T, Imoto A Knowledge and practices towards reproductive health among rural women in the southern region of Jordan. East Mediterr Health J. 2012;18(6):567-72. PMID:22888612

15. Babalola S, Fatusi A. Determinants of use of maternal health services in Nigeria looking beyond individual and house- hold factors. BMC Pregnancy Childbirth. 2009;9(43):43. PMID:19754941

16. Filippi V, Ganaba R, Baggaley RF, Marshall T, Storeng KT, Sombié I, et al. Health of women after severe obstetric complications in Burkina Faso: a longitudinal study. Lancet. 2007 Oct 13;370(9595):1329-37. PMID:17933647

17. Hogan MC, Foreman KJ, Naghavi M, Ahn SY, Wang M, Makela SM, et al. Maternal mortality for 181 countries, 1980-2008: a systematic analysis of progress towards Millennium Development Goal 5. Lancet. 2010 May 8;375(9726):1609-23. PMID:20382417 